\title{
DNA Checkerboard Method for Bacterial Pathogen Identification in Oral Diseases
}

\author{
Método de Chequeo de DNA para la Identificación de Bacterias Patógenas \\ en las Enfermedades de la Cavidad Oral \\ "Cássio do Nascimento; *João Paulo Mardegan Issa; **Evandro Watanabe \& **Izabel Yoko Ito
}

NACIMENTO, C.; ISSA, M. J. P.; WATANABE, E. \& ITO, Y. I. DNA checkerboard method for bacterial pathogen identification in oral diseases. Int. J. Morphol., 24(4):619-624, 2006.

SUMMARY: This work aim to show by literature review the principal characteristics of the DNA checkerboard method for bacterial pathogens identification in oral diseases, showing the most varieties uses and applications of this technique.

KEY WORDS: DNA Checkerboard; DNA probes; Microbiology; Bacteria.

\section{INTRODUCTION}

Osseointegrated dental implants to replace lost teeth in edentulous and partially edentulous patients have become a predictable treatment modality in restorative dentistry. Longitudinal studies have reported high survival and success rates for osseointegrated titanium implants (Esposito et al., 1998). Favourable long-term results of dental implant systems have been reported (Albrektsson, 1988). However, implant failure may occur (Esposito et al.; Tanner et al., 1997). Breakdown of peri-implant tissues can occur due to mechanical stress or peri-implant infection leading to loss of the implant (Mombelli et al., 1987; Alcoforado et al., 1991; Rosenberg et al., 1991).

In addition to successful treatment, low amounts of plaque and low levels of marginal inflammation have been identified at the implants (Adell et al., 1981, 1986; Lekholm et al., 1986, 1999; Leonhardt et al., 1992; Mombelli et al., 2001). Despite the predictable treatment results, with most failures occurring during initial healing and the first year of loading, complications do arise during maintenance and retention of implants. The tissues supporting osseointegrated dental implants are susceptible to disease that may lead to implant loss (Malmström et al., 1990; Lindhe et al., 1992).
Dental plaque is a biofilm containing approximately 500 microbial species (Moore \& Moore, 1991; Paster et al., 1998). Biofilm is also the primary causative agent of dental caries (tooth decay) with a range of predominantly Grampositive putative pathogens (Loesche, 1986). Potentially pathogenic species include a range of "low $\mathrm{pH}$ Streptococci," Actinomyces and Bifidobacterium spp, and Candida albicans (Bauman et al., 1992; Bowden, 1999). It is the biofilm communities themselves, as distinct entities that are the causative agents of biological processes such as dental caries, periodontal disease and peri-implantitis, rather than any single organism slipping past the host defense and causing periodontal tissue breakdown. Initially, the unspecific plaque theory dominated, but later it became evident that every biofilm differs from others, and that only the selection of some specific species can lead, under certain circumstances, to disease.

Peri-implantitis, i.e. chronic progressive marginal infection, is defined as an inflammatory reaction affecting the tissues surrounding osseointegrated dental implants resulting in loss of supporting bone (Albrektsson \& Isidor, 2001; Mombelli \& Lang, 1998; Esposito et al., 1998). The view that microorganisms play a major role in the

\footnotetext{
* Department of Dental Materials and Prosthodontics, Faculty of Dentistry of Ribeirão Preto, University of São Paulo, Brasil.

** Department of Toxicological and Bromatologic Clinical Analysis, Faculty of Pharmaceutical Sciences of Ribeirão Preto, University of São Paulo, Brasil. This study was supported by FAPESP (No. 03/04585-1).
} 
development of peri-implantitis is supported by several clinical findings. A cause-related effect between plaque accumulation and peri-implant mucositis has been shown in animals and in humans (Berglundh et al., 1992; Pontoriero et al., 1994). The microbial colonization of implants follows the same pattern as that around teeth (Leonhardt et al., 1992). A positive correlation has been found between oral hygiene and marginal bone loss around implants in the edentulous mandible (Lindquist et al., 1996). During peri-implant breakdown a complex microbiota is established, closely resembling that found in adult periodontitis (Becker et al., 1990; Rams \& Link 1983, Rams et al. 1991; Rosenberg et al.; Alcoforado et al.; Augthun \& Conrads, 1997). When peri-implant tissue breakdown is induced by placing plaque retentive ligatures submarginally, a shift in the microflora occurs (Leonhardt et al., 1992). Apart from dark-pigmented Gram-negative anaerobic rods, other bacterial species associated with periimplant infection include Bacteroides forsythus, Fusobacterium nucleatum, Camphylobacter, Peptostreptococcus micros, and Streptococcus intermedius (Tanner et al.). Organisms not primarily associated with periodontitis, such as Staphylococcus spp., Enterics and Candida spp. have also been found in peri-implant infection (Slots \& Rams, 1991; Leonhardt et al., 1999). Although the microbiological profile at failing implants differs from that in periimplant health, it is not known whether the host response to the bacterial challenge is similar to that seen in periodontitis.

In order to understand the role of plaque in maintaining periodontal health or initiating disease, it is necessary to determine plaque composition in different clinical states. The early studies on biofilm composition employed light microscopy, but this method was incapable of distinguishing the wide array of resident species and has been discarded. Culture techniques are very time consuming, especially when all species have to be identified, and sometimes inadequate to recover some difficult to culture species (Sakamoto et al., 2005). The DNACheckerboard technique overcomes many of the limitations of culture, is faster and more cost-effective (Socransky et al., 1994).

DNA Checkerboard is a recently established technique that gives a simultaneous and quantitative analysis of up to 28 plaque samples against 40 microbial species (Socransky et al., 1994). It was developed initially to study the predominantly Gram-negative subgingival microorganisms involved in periodontitis (Socransky et al., 1998). DNA Checkerboard method offers the ability to include more potential periodontal pathogens in large-scale studies with a single analysis than is usually practicable with cultural analysis. These new probe-target format permits enumerate a large numbers of species in very large numbers of samples. This will enable a more detailed evaluation of the clinical and epidemiological relationships of the complex plaque microbiota with respect to the development of oral diseases. For this analysis, 28 dental sample plaques, and DNA standards representing $10^{5}$ and $10^{6}$ cells for target species are fixed on a membrane in thin lanes, then simultaneously cross-hybridized with 40 labeled, whole genome probes (Fig. 1). Using this technology, Socransky et al., 1998, 2002, 2004, showed that a set of clusters of species related to the development of periodontitis existed in dental plaque. Some of these clusters enabled the establishment of a pathogen complex, which in turn allowed the establishment of the major pathogens causing periodontitis (Table I).

Thus, the aim of this work is to present, by a literature review, the use of the DNA Checkerboard method for bacterial pathogens identification in oral diseases.
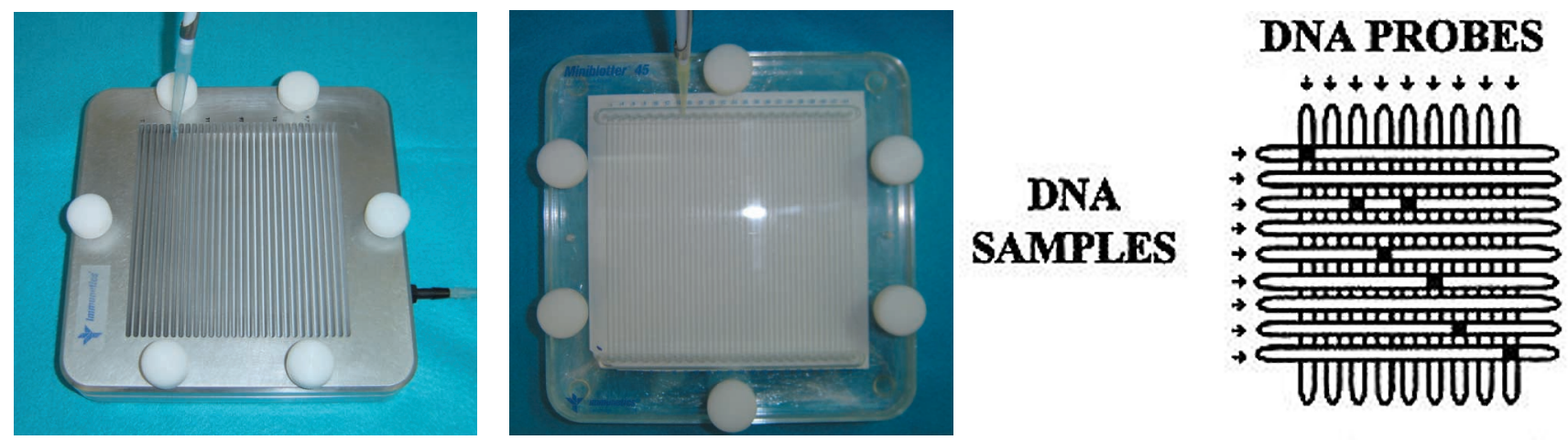

Fig.1. Example of DNA - Checkerboard hybridization to detect bacterial species tested against dental plaque samples. A: Samples applied into the extended slots of the MiniSlot apparatus, and then concentrated into a 15x15 cm nylon membrane; B: Application of labeled probes on individual slots in the MiniSlot apparatus; C: The horizontal lanes numbered 1 to 28 are the plaque samples, and the two vertical lanes on the right are standards containing either $10^{5}$ or $10^{6}$ cells in each tested species. The vertical lanes contain the indicated DNA probes in hybridization buffer. 
DNA checkerboard method for bacterial pathogen identification in oral diseases. Int. J. Morphol., 24(4):619-624, 2006.

\begin{tabular}{|c|c|}
\hline Complexes & Bacterial species \\
\hline Purple & V.parvula, A.odontolyticus \\
\hline Yelow & Streptococci spp.: S.mitis, S.oralis, S.sanguis, S.gordonii, S.intermedius \\
\hline Green & $\begin{array}{l}\text { E.corrodens, C.gingivalis, C.sputigena, C.ochracea, C.concisus, } \\
\text { A.actinomycetemcomitans serotype a }\end{array}$ \\
\hline Orange & $\begin{array}{l}\text { P.intermedia, P.nigrescens, P.micros, C.gragilis, C.rectus, F.periodonticum, } \\
\text { F.nuc.nucleatum, F.nuc.vincentii, S.constellatus, E.nodatum, C.showae, } \\
\text { F.nuc.polymorphum }\end{array}$ \\
\hline Red & $\begin{array}{l}\text { P.gingivalis, B.forsythus, T.denticola } \\
\text { A. viscosus, Selenomonas noxia, A.actinomycetemcomitans serotype } b\end{array}$ \\
\hline
\end{tabular}

Table 1. Microbial complexes in subgingival plaque according to Socransky et al., 1998.

\section{DISCUSSION}

The DNA Checkerboard hybridization technique has been used to comprehensively examine the microbial composition of supra and subgingival plaque in subjects in health and periodontitis, the salivary microbiota levels in relation to periodontal status, the relationship of cigarette smoking to the composition of the subgingival microbiota (Ximenez-Fyvie et al., 2000; Sakamoto et al.), the differences between the subgingival microbiota in subjects from different geographic locations, the relationship of ethnic/racial group, occupational and periodontal disease status, and effects of different periodontal therapies (Colombo et al., 1998; Haffajee et al., 1998; Ximenez-Fyvie et al.). Recently, it was reported that this hybridization technique is useful for the enumeration of bacterial species in microbiologically complex systems. This technique is rapid, sensitive, and relatively inexpensive (Socransky et al., 1994).

Whole genomic DNA probes have been used extensively in studies evaluating the composition of subgingival plaque and the microbiota associated with endodontic lesions (Haffajee et al.; Ximenez-Fyvie et al.; Siqueira et al., 2002). Whole genomic probes are constructed using the entire genome of a bacterial species as the target. One of the criticisms of these probes is that the use of the entire genome may increase the probability of cross-reactions between species because of common regions of DNA among closely related species. Other concerns have been that the whole genomic DNA probes might not detect all strains of a given species and that the probes would have a low sensitivity in terms of the numbers of cells that they detect. Investigations at the Forsyth Institute, however, using whole genomic DNA probes have indicated that many of the concerns regarding their use are unjustified or can be overcome. DNA probes can be very effective for the detection of bacterial species, but when employed in the typical format, only limited numbers of probes can be employed to enumerate relatively large numbers of samples. Checkerboard format procedures, whether employing direct or reverse hybridization procedures, can extend markedly the number of samples evaluated for a wide range of bacterial species.

The DNA Checkerboard hybridization technique outlined in this manuscript offers a number of advantages for the study of multiple species of bacteria in large numbers of samples containing complex mixtures of microorganisms. The technique is rapid, sensitive, and relatively inexpensive. It overcomes many of the limitations of cultural microbiology including loss of viability of organisms during transport, the problem of enumerating difficult to cultivate species, and the difficulty encountered in speciating certain taxa that are difficult to grow or which exhibit few positive phenotypic traits. Another advantage is that the entire sample may be employed without dilution or amplification, overcoming problems in quantification imposed by either serial dilution or PCR amplification procedures. Finally, the technique provides quantitative data which may be important in treatment studies of biofilm infections where species levels and proportions may be markedly decreased but the species not eliminated. Another advantage of the technique is that 
membranes may be stripped and re-probed with a new set of 40 different DNAprobes.

The DNA checkerboard technique does have limitations. The technique can detect only species for which DNA probes have been prepared. Thus, novel pathogens or environmentally important species which might be detected in culture or by other molecular techniques would not be detected by this method. The technique must be optimized for a given biological or environmental site. The use of probes developed for subgingival plaque samples is unlikely to be optimum for samples for other body sites or other sites in nature. The probes must be used to detect organisms in samples of the appropriate size. Probes optimized to detect species in the $10^{4}$ and $10^{7}$ range often will provide crossreactions if much larger samples are employed. When properly employed, DNA Checkerboard hybridization and other rapid microbiological techniques permit investigation of etiologic, therapeutic, and environmental problems which could not be approached by other means.

\section{CONCLUSIONS}

It was possible to conclude that: 1 . With the advancement of molecular biology in recent years, the initiation and progression mechanisms of periodontitis are becoming clearer gradually. As the culture-independent approaches have revealed the diversity of human oral microbiota and the existence of a large number of as-yet-tobe-cultured organisms which are presumed as periodontal pathogens, the researches on periodontal disease and human oral microbiota are coming to a new turn.

DNA Checkerboard hybridization is a powerful and fast identification method in the clinical laboratory. This technique is applicable for routine identification of several groups of bacteria as well as for identification of novel isolates. As the technical resources for bacterial identification become more abundant and less expensive, more microbiologists will consider using this method in their studies.

NACIMENTO, C.; ISSA, M. J. P.; WATANABE, E. \& ITO, Y. I. Método de chequeo de DNA para la identificación de bacterias patógenas en las enfermedades de la cavidad oral. Int. J. Morphol., 24(4):619-624, 2006.

RESUMEN: Este trabajo tiene como objetivo, presentar en una revisión de la literatura, las principales características del método de chequeo del DNA para la identificación de bacterias patógenas en la cavidad oral, mostrando las diferentes utilizaciones y aplicaciones de esta técnica.

PALABRAS CLAVE: Cheque de DNA; Sonda de DNA; Microbiología; Bacteria.

\section{REFERENCES}

Adell, R.; Lekholm, U.; Rockler, B. \& Branemark, P. I. A 15 -year study of osseointegrated implants in the treatment of the edentulous jaw. Int. J. Oral. Surg., 10(6): 387-416, 1981.

Adell, R.; Lekholm, U.; Rockler, B.; Branemark, P. I.; Lindhe, J.; Eriksson, B. \& Sbordone, L. Marginal tissue reactions at osseointegrated titanium fixtures. A 3-year longitudinal prospective study. Int. J. Oral Maxillofac. Surg., 15(1):39-52, 1986.

Albrektsson, T. A multicenter report on osseointegrated oral implants. J. Prosthodontic Dentistry., 60:75-84, 1988.

Albrektsson, T \& Isidor, F. Consensus report of session IV. In: Lang, N.P. \& Karring, T. eds. Proceedings of the 1st European Workshop on Periodontology 1993, 365-9. London, Berlin, Quintessence Publishing Company, 2001.
Alcoforado, G. A. P.; Rams, T. E.; Feik, D \& Slots, J. Microbial aspects of failing osseointegrated dental implants in humans. J. de Parodontologie, 10:11-8, 1991.

Augthun, M. \& Conrads, G. Microbial findings of deep peri-implant bone defects. Int. J. of Oral and Maxillofacial Implants, 12:106-12, 1997.

Bauman, G. R.; Mills, M.; Rapley, J. \& Hallmon, W.W. Plaqueinduced inflammation around implants. Int. J. Oral Maxillofac Implants, 7:330-7, 1992.

Becker, W.; Becker, B. E.; Newman, M. G. \& Nyman, S. Clinical and microbiologic findings that may contribute to dental implant failure. Int. J. Oral. Maxillofac. Implants, 5:31-8, 1990.

Berglundh, T.; Lindhe, J.; Marinello, C.; Ericsson, I. \& 
Liljenberg, B. Soft tissue reaction to de novo plaque formation on implants and teeth. An experimental study in the dog. Clinical Oral Implants Research., 3:1-8, 1992.

Bowden, G. H. Controlled environment model for accumulation of biofilms of oral bacteria. Methods Enzymol., 310:216-24, 1999.

Colombo, A. P.; Haffajee, A. D.; Dewhirst, F. E.; Paster, B. J.; Smith, C. M.; Cugini, M. A. et al. Clinical and microbiological features of refractory periodontitis. $J$. Clin. Periodontol., 25:169-80, 1998.

Esposito, M.; Hirsh, J. M.; Lekholm, U. \& Thompsen, P. Biological factors contributing to failures of osseointegrated oral implants. European J. of Oral Sciences, 106:527-51, 1998.

Haffajee, A. D.; Cugini, M. A.; Tanner, A.; Pollack, R. P.; Smith, C.; Kent, R. L. Jr., et al. Subgingival microbiota in healthy, well-maintained elder and periodontitis subjects. J. Clin. Periodontol., 25:346-53, 1998.

Lekholm, V.; Adell, R.; Lindhe, J.; Branemark, P. I.; Eriksson, B.; Lindvall, A. M. \& Yonoyama, T. Marginal tissue fractions at osseo integrated titanium fixtures (II) A crosssectional retrospective study. Int. J. Oral Maxillofac. Surg., 15:53-61, 1986.

Lekholm, V., Gunne, J.; Henry, P.; Higuchi, K.; Lindon, V.; Berstrom, C. \& van Steenberghe, D. Survival of the branemark implant in partially edentulous jaws: a 10 year prospective multicenter study.

Leonhardt, A.; Berglundh, T.; Ericsson, I. \& Dahle'n, G. Putative periodontal pathogens on titanium implants and teeth in experimental gingivitis and periodontitis in beagle dogs. Clin. Oral Implants Res., 3:112-9, 1992.

Leonhardt, A.; Renvert, S. \& Dahle'n, G. Microbial findings at failing implants. Clinical Oral Implants Research, 10: 339-45, 1999.

Lindhe, J.; Berglundh, T.; Ericsson, I.; Liljenberg, B. \& Marinello, C. Experimental breakdown of peri-implant and periodontal tissues. A study in the beagle dog. Clinical Oral Implants Research., 3: 9-16, 1992.

Lindquist, L. W.; Carlsson, G. E. \& Jemt, T. A prospective15year follow-up study of mandibular fixed prostheses supported by osseointegrated implants. Clinical results and marginal bone loss. Clinical Oral Implants Research, 7:329-36, 1996.
Loesche, W. J. Importance of nutrition in gingival crevide microbial ecology. Periodontics., 6(6):245-9, 1968.

Malmström, H. S.; Fritz, M. E.; Timmis, D. P. \& Van Dyke, T. E. Osseointegrated implant treatment of a patient with rapidly progressive periodontitis. A case report. J. of Periodontology., 61:300-4, 1990.

Mombelli, A.; Van Oosten, M.A.C.; Schurch, E.; Lang, N.P. The microbiota associated with sucessful or failing osseointegrated titanium implants. Oral Microbiology Mand. Immunology., 2:145-51, 1987.

Mombelli, A.; Lang, N. P. The diagnosis and treatment of periimplantitis. Periodontology, 5:56-60, 1998.

Mombelli, A.; Burgin, W; Buser, D; Lang, N. P. \& Rutar, A. Retrospective assessment of clinical and microbiological factors affecting periimplant tissue conditions. Clin. Oral Impl. Res., 12:189-95, 2001.

Moore, W. E.; Moore, L. H.; Ranney, R. R.; Smibert, R. M.; Burmeister, J.A. \& Schenkein, H.A. The microflora of periodontal sites showing active destructive progression. J. Clin. Periodontol., 18:729-39, 1991.

Paster, B. J.; Bartoszyk, I. M. \& Dewhirst, F. E. Identification of oral streptococci using PCR-based, reverse-capture, checkerboard hybridization. Methods Cell. Sci., 20:22331, 1998.

Pontoriero, R.; Tonelli, M. P.; Carnevale, G.; Mombelli, A.; Nyman, S. R. \& Lang, N.P. Experimentally induced periimplant mucositis. A clinical study in humans. Clin. Oral Implants Res., 5:254-9, 1994.

Rams, T. E. \& Link, C. C. Jr. Microbiology of failing dental implants in humans: electron microscopic observations. J. of Oral Implantology, 11:93-100, 1983.

Rams, T. E.; Roberts, T. W.; Feik, D.; Molzan, A. K. \& Slots, J. Clinical and microbiological findings on newly inserted hydroxyapatite-coated and pure titanium human dental implants. Clin. Oral Implants Res., 2: 121-7, 1991.

Rosenberg, E. S.; Torosian, J. P. \& Slots, J. Microbial differences in two clinically distinct types of failures of osseointegrated implants. Clin. Oral Implants Res., 2. 135-44, 1991.

Sakamoto, M.; Umeda, M. \& Benno, Y. Molecular analysis of human oral microbiota. J. Periodont. Res., 40:277$85,2005$. 
Siqueira, J. F.; Rocas, I. N.; De Uzeda, M.; Colombo, A. P. \& Santos, K. R. Comparison of 16S rDNA-based PCR and checkerboard DNA-DNA hybridization for detection of selected endodontic pathogens. J. Med. Microbiol., 51: 1090-6, 2002.

Slots, J. \& Rams, T. E. New views on periodontal microbiota in special patient categories. J. of Clinical Periodontology, 18:411-20, 1991.

Socransky, S. S.; Smith, C.; Martin, L.; Paster, B. J.; Dewhirst, F. E. \& Levin, A. E. Checkerboard DNADNA hybridization. Biotechniques, 17:788-92, 1994.

Socransky, S. S.; Haffajee, A. D.; Cugini, M. A.; Smith, C. \& Kent, R. L. Jr. Microbial complexes in subgingival plaque. J. Clin. Periodontol., 25:134-44, 1998.

Socransky, S.S.; Haffajee, A.D. Dental biofilms: difficult therapeutic targets. Periodontology, 28:12-55, 2002.

Socransky, S. S.; Haffajee, A. D.; Smith, C. et al. Use of checkerboard DNA-DNA hybridization to study complex microbial ecosystems. Oral Microbiol. Immunol., 19:352-62, 2004.

Tanner, A.; Maiden, M. F. J.; Lee, K; Shulman, L. B. \& Weber, H.P. Dental implant infections. Clinical Infectious Diseases., 25 (suppl2):S213-7, 1997.

Ximenez-Fyvie, L. A.; Haffajee, A. D. \& Socransky, S.S. Comparison of the microbiota of supra- and subgingival plaque in subjects in health and periodontitis. J. Clin. Periodontol., 27:648-57, 2000.
Correspondence to:

Dr. Cássio do $\mathcal{N a s c i m e n t o}$

Rua Garibaldi, 805 apto 102

CEP 14010-170

Ribeirão Preto-SP, Brazil

Business: $\mathcal{T e l} .:+55-16-3602-4095$

Fax: +55-16-3633-0999

Home: Tel.: +55-16-3635-7457

E-mail:cassionasc@forp.usp.br

Received: 28-06-2006

Accepted: 28-09-2006 